\title{
MONITORING OF SURFACE DISPLACEMENTS IN THE KALOCHORI AREA (THESSALONIKI, GREECE) USING A LOCAL GNSS NETWORK
}

\author{
Ganas A. ${ }^{1}$, Chousianitis K. ${ }^{1}$, Argyrakis P. ${ }^{1}$, Tsimi Ch. ${ }^{1}$, Papanikolaou M. ${ }^{1}$, \\ Papathanassiou G. ${ }^{2}$ and Exarchos K. ${ }^{1}$ \\ ${ }^{1}$ Institute of Geodynamics, National Observatory of Athens, 11810 Athens, Greece, \\ aganas@noa.gr,chousianitis@noa.gr,pargyrak@noa.gr \\ ${ }^{2}$ Aristotle University of Thessaloniki, Department of Geology, 54124, Thessaloniki, Greece
}

\begin{abstract}
The ground motions in the Kalochori region (well known for its subsidence history during the $2^{\text {nd }}$ half of $20^{\text {th }}$ century) were investigated by NOA using a mobile GNSS (GPS) network, comprising 18 stations. The network was measured four (4) times during the period October 2013 - April 2015 under the framework of the research project INDES-MUSA. Our GPS measurements were processed with GAMIT software and show vertical (ITRF 2008) motions ranging from $-2 \mathrm{~cm}$ to $+2 \mathrm{~cm}$ (i.e. just above the margins of measurement error) with the exception of the Kalochori dam where an uplift of 2-5 cm was observed. We also found no evidence for local (non-tectonic) motions and/or interseismic strain.
\end{abstract}

Keywords: subsidence, GPS, multipath, groundwater, IDW, INDES-MUSA.

\section{Пєрі́ $\eta \psi \eta$}

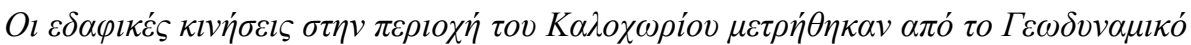

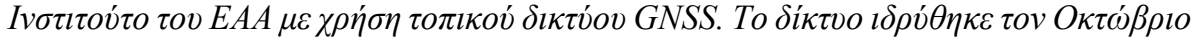

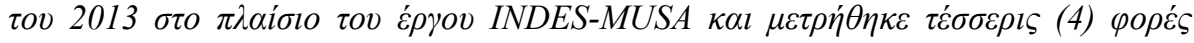

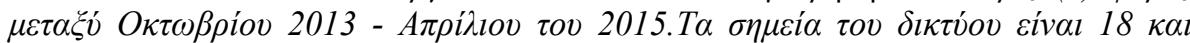

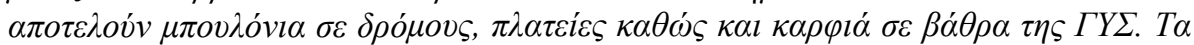

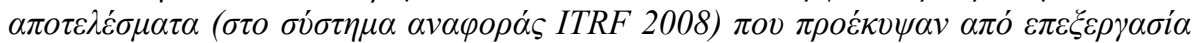

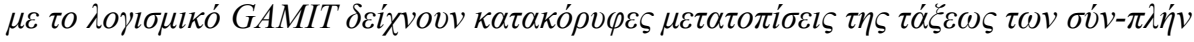

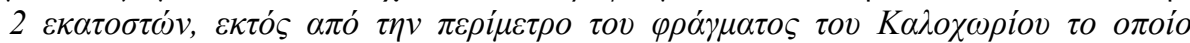

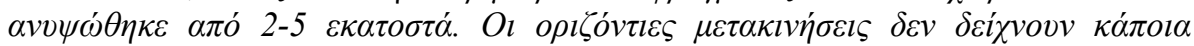

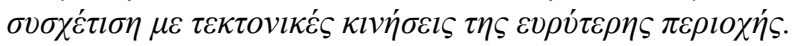

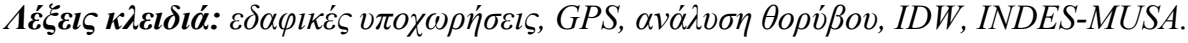

\section{Introduction}

The area under study, the broader area of Kalochori, is located at the eastern part of Thessaloniki plain. Major part of this plain was formed in the last 5000 years as the prograding delta of four Macedonian rivers (Gallikos, Axios, Loudias and Aliakmon). At least till the 1920's when Kalochori village was established by Greek refugees from Asia Minor and Eastern Thrace, the broader area was covered by swamps, lagoons, small lakes and river floodplains, but following the construction of extensive water discharge channels, coastal barriers and artificial levees, it was subsequently occupied by an industrial centre and a small town (in the 1960's and 1970's). The rapid development 
led to an increasing need for water, provided by productive wells. Furthermore overexploitation of the aquifers of the lower river Gallikos (including Kalochori region) was enhanced by water overpumping conducted by the Water Supply Organisation of Thessaloniki to meet the increasing needs of Thessaloniki, since these were the main providers (at that time) of drinking water. The effects of subsidence in the Kalochori region were first noticed in the early 1960's. Since then, the morphological and environmental setting of the region has greatly changed. In particular, comparison of maps and aerial photos covering a period of up to 40 years and of more recent geodetic data revealed that in the Kalochori area a cumulative subsidence of several metres had occurred between 1955-1980, with annual rates of the order of up to $10 \mathrm{~cm}$ locally (Stiros, 2001; Doukas et al., 2004). The land subsidence, which locally exceeded $3 \mathrm{~m}$, caused a marine invasion, which was firstly noticed in 1965 and few years later, in 1969, during a period of intensive rainfall the sea reached the southernmost houses of the village.

The land subsidence in the Kalochori region has been studied during the last 25 years by many researchers, who have supplied an extensive set of geological, geotechnical and geodetic data. Stiros (2001) stated that until the 1980 `s, the maximum subsidence regions (subsidence $>3 \mathrm{~m}$ ) were coinciding with the areas containing the pumping wells of the Water Supply Organisation of Thessaloniki and with the south-western section of the industrial area containing the most waterconsuming industries. According to Badelas et al. (1996) the subsidence rate in Kalochori region ranged from -3 to $-13 \mathrm{~cm} / \mathrm{yr}$. The outcome of this study was based on land-based geodetic measurements conducted from September 1992 to July 1995. In addition, Doukas et al. (2004) estimated that the subsidence rate varied from -2.8 to $-5 \mathrm{~cm} / \mathrm{yr}$ by measuring a leveling network consisting of 37 stations, for a period of ten years, 1992 - 2002. Although the majority of the researchers assign the subsidence mainly to reservoir compaction (Andronopoulos et al., 1990, 1991; Hatzinakos et al., 1990; Rozos and Hatzinakos, 1993; Loupasakis and Rozos, 2009) other interpretations have also been proposed. According to Stiros (2001) possible additional causes of the ground subsidence are: (1) the consolidation of near-surface sediments; (2) the oxidation of peat soils in the vadose zone; (3) the synsedimentatary deformation of the delta; (4) the subsurface instability of the delta-front mud caused by the consolidation of relatively deep layers. Doukakis (2005) reported that the rapid sea invasion, as well as the land subsidence, is amplified by coastal erosion and by a sea-level rise caused by climate changes. Psimoulis et al. (2007) attributed the subsidence to a large-scale natural effect on which smaller-scale anthropogenic effects, such as compaction caused by water pumping, are superimposed. In contrast, Dimopoulos (2005) claimed that the subsidence in the Kalochori region is caused by the consolidation of the loose silty-clay deposits and by a flowing sand phenomenon taking place close to the coastline.

\section{GNSS network}

The geodetic network in the broader area of Kalochori consists of eighteen (18) points. It was established by the National Observatory of Athens during October 2013 (see map in Figure 1) following the implementation timetable of the project INDES-MUSA (Rovithis et al., 2014). The main aim of the establishment of the network was to monitor the subsidence of Kalochori area and its connection (interaction) with the neighbouring active faults of central Macedonia incl. the Mygdonia basin (i.e. Pavlides and Kilias, 1987). Strict criteria were set while selecting the location of the stations in order to ensure stable installations, unobstructed horizon view and avoidance of the multipath effect. All the geodetic benchmarks were manufactured on artificial surfaces. We expect the benchmarks to be stable and that the possible movements we observe are due to deformation.

The Kalochori Network has been measured already four times (2013, 2014a, 2014b and 2015; observation days are 304, 101, 308 and 093 respectively) and static, GNSS observations were recorded in RINEX format. 


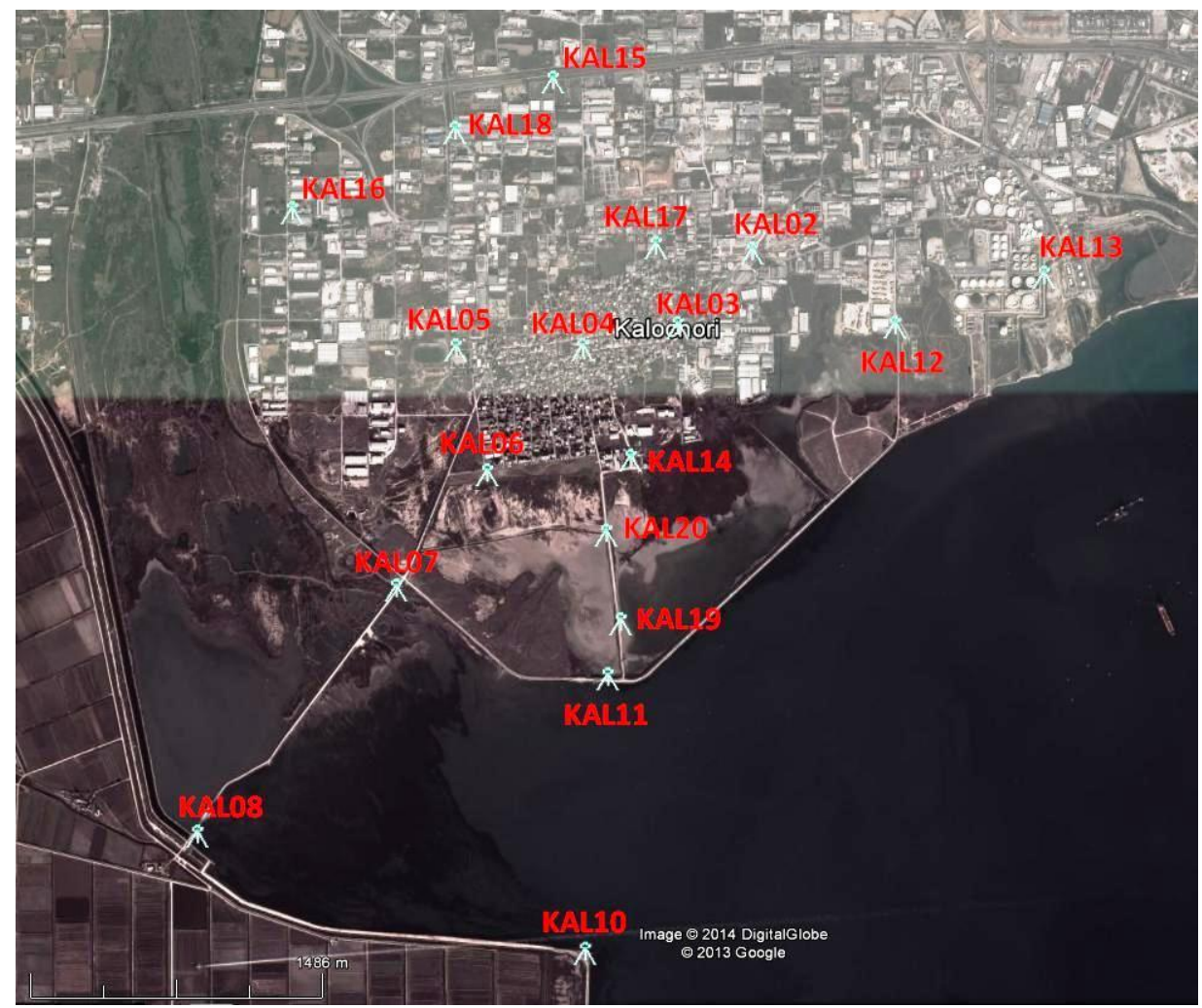

Figure 1 - Google 2014 image of Kalochori showing non-permanent GNSS stations (cyan tripods).
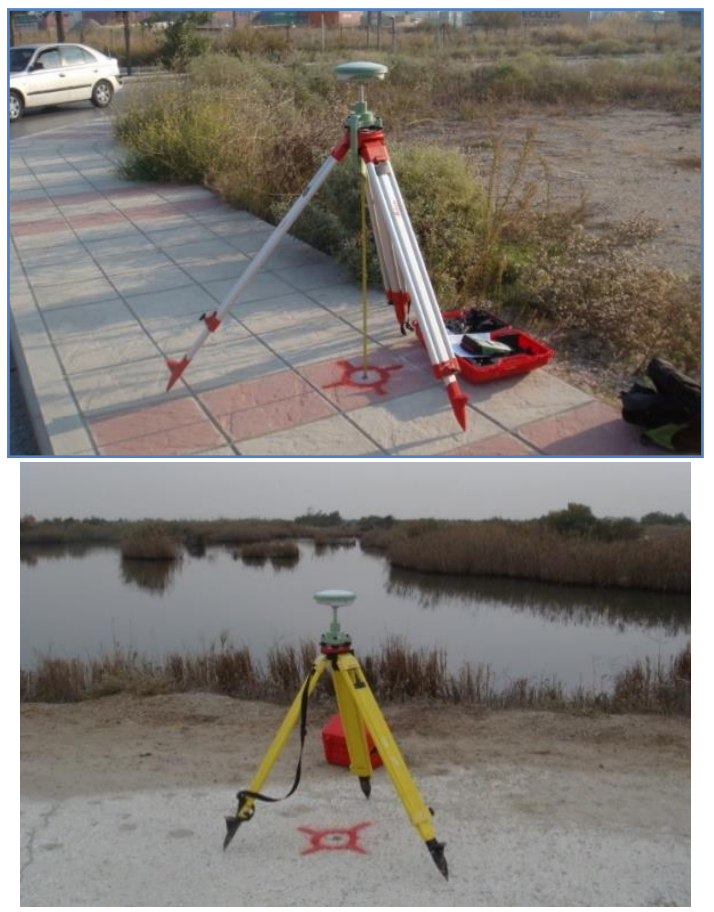

Figure 2 - Field photographs during occupation of GNSS stations in Kalochori, left is station KA02 (urban, against DORAL factory) and on the right is station KA07 (lagoon). See Fig. 1 for location map. 
Although Global Navigation Satellite System (GNSS), includes GPS, GLONASS and upcoming Galileo satellites in this paper we present results from GPS observations only. The geodetic equipment used is LEICA GS08PLUS (three instruments). The sessions of measurements were about 4-5 hrs per point, each session. The first day of each measurement campaign only six (6) of the geodetic points were occupied, followed by another six (6) during the second day and finally six (6) during the third and final day. The observation sampling interval was 15 -s in all campaigns. To measure the network we used tripods and height hooks (Figure 2) following this procedure: 1) Position tripod over benchmark 2) Attach tribrach to tripod 3) Use tribrach bull's eye level to level tripod. 4) Move tripod legs to center optical plumb on monument and to level tribrach bull's eye level. 5) Make sure tripod legs are tightly secured and weighted down in windy days 6) Measure vertical antenna height using height hook 7) Attach antenna mount to antenna and plug coaxial antenna cable into antenna. All field metadata were recorded on campaign forms. In Figure 1 the distribution of the GNSS network is presented.

\section{GPS data quality analysis}

GNSS data quality analysis includes information about the receiver clock slips, receiver cycle slips, multipath, receiver SNR, and other useful parameters and tracking statistics. We analysed our data for the most important quality indices, however, for convenience of the reader we only present our analysis on multipath effects. Multipath interference occurs when the mobile station receives reflected signals in addition to the direct LOS (line of sight) GNSS signal. These interference signals are generally reflected from the ground, buildings or trees. Multipath remains a dominant source of ranging error in GNSS and as such it has to be estimated in our data. For this purpose all campaign data were analysed by use of TEQC software, distributed by UNAVCO (Estey and Meertens, 1999). The multipath graphs are shown in Figure 3 for all four campaigns. Only three (3) out of eighteen (18) stations exhibit multipath in L1 frequency $>0.2 \mathrm{~m}$ and in L2 $>0.25 \mathrm{~m}$, respectively. Usually, L2 multipath estimate (MP2) is much higher than the (MP1) estimate; this is confirmed here, except for stations KA03 and KA07 during campaign 2. Worst station in terms of multipath is KA16 (min $0.17 \mathrm{~m}$ - max is $0.47 \mathrm{~m}$; Fig. 4) with second worst station KA02 ( $\min 0.15 \mathrm{~m}$ - max is $0.32 \mathrm{~m}$; Fig. 2 left), both urban stations. Best station with less multipath is KA20 (min $0.02 \mathrm{~m}-\max$ is $0.04 \mathrm{~m}$; Fig. 4), a lagoon station. The average values for the autumn campaigns is $\mathrm{MP} 1_{\mathrm{A}} 0.10 \mathrm{~m}, \mathrm{MP} 2_{\mathrm{A}} 0.12$ $\mathrm{m}$ and $\mathrm{MP} 1_{\mathrm{C}} 0.10 \mathrm{MP} 2_{\mathrm{C}} 0.11 \mathrm{~m}$, respectively. The average values for the spring campaigns is $\mathrm{MP} 1_{\mathrm{B}}$ $0.09 \mathrm{~m} \mathrm{MP} 2_{\mathrm{B}} 0.11 \mathrm{~m}$ and $\mathrm{MP} 1_{\mathrm{D}} 0.09 \mathrm{~m} \mathrm{MP} 2_{\mathrm{D}} 0.12 \mathrm{~m}$, respectively.

\section{Data processing and surface displacements of GNSS stations}

Towards the realisation of the "campaign" method of GPS observation, the NOA team obtained four (4) sets of 3-D coordinates measured at the same station but at different times. When these sets are compared successively, changes in three-dimensional coordinate can be used to calculate the surface displacements among campaigns of which the component of interest is the vertical one (see Table 1 for results).

During all campaigns, a minimum of 4 hours of recording was achieved at all benchmarks, with 15s sampling period and elevation cut-off angle of $10^{\circ}$. The campaign data were analyzed via the GAMIT/GLOBK software package (Version 10.4; Herring et al., 2010) following a rigorous approach as described in Chousiantis et al. (2015). GAMIT uses double-differenced phase measurements (ionosphere-free linear combinations of the L1 and L2) to generate weighted leastsquares solutions for each daily session. We used International GNSS Service (IGS) final products (orbits, clocks and earth orientation parameters), absolute transmitter/receiver calibration corrections and differential code bias values published by Centre for Orbit Determination in Europe (CODE) Analysis Centre.

The effect of solid-earth tides, polar motion and oceanic loading was taken into account according to the IERS/IGS standard 2003 model (McCarthy and Petit, 2004). 

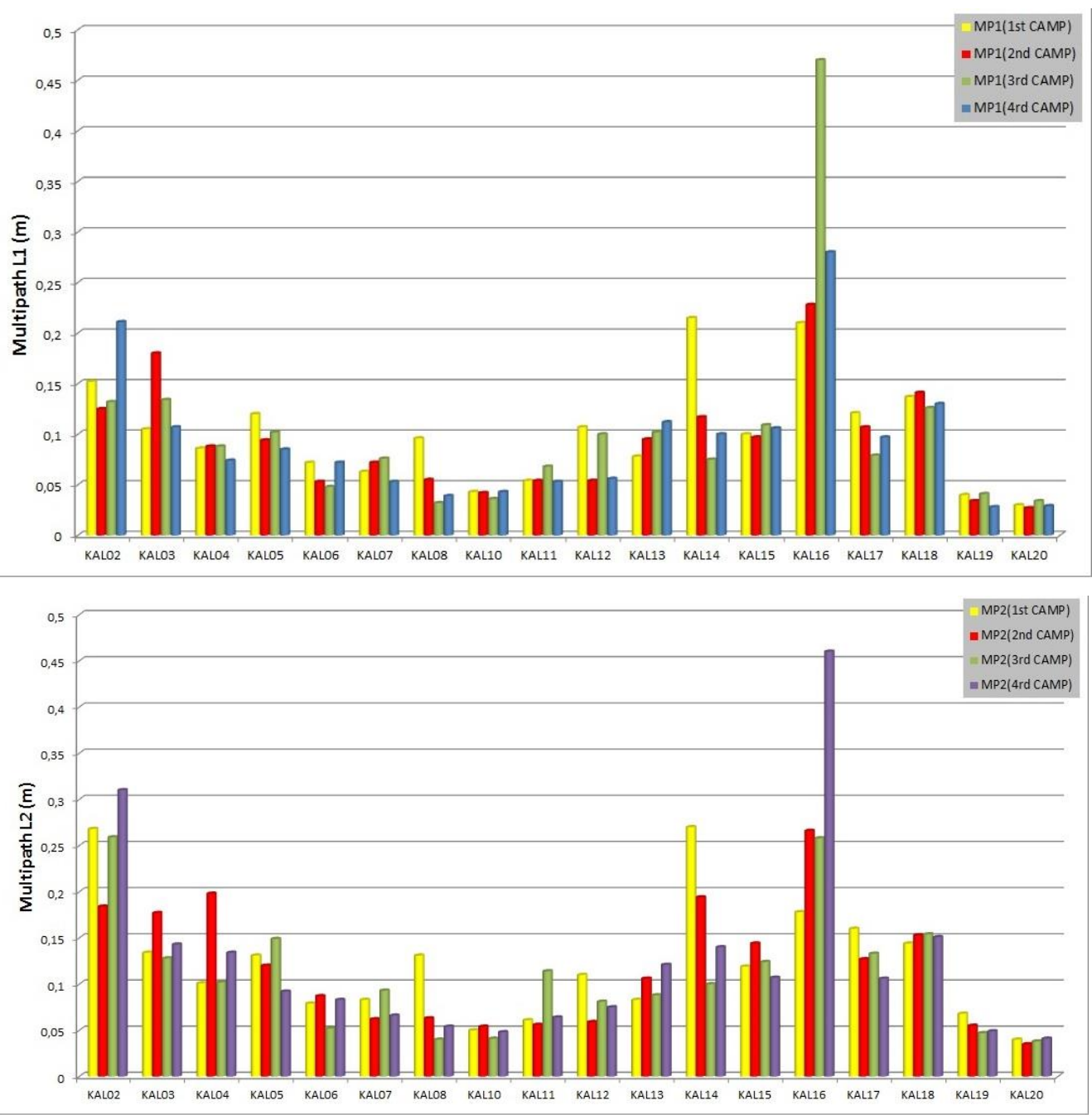

Figure 3 - Data quality graphs showing multipath per mobile GNSS station in L1 frequency (top), multipath in $\mathrm{L} 2$ frequency (bottom).

We applied the ocean-loading model FES2004 and used IGS absolute elevation and azimuth dependent tables for modelling the effective phase centre of the receiver and satellites antennas. The accepted percentage of resolved ambiguities was set to 70\%. An automatic cleaning algorithm was applied to post-fit residuals in order to repair cycle slips and to remove outliers. For each session, we obtained two solutions based on phase ambiguity resolution, one bias-free and one bias-fixed, along with the associated variance-covariance matrices. Next, we combined our loosely constrained bias-fixed solutions of our local network with analysed global and regional solutions provided by SOPAC (http://sopac.ucsd.edu) into single day unconstrained solutions. Finally, we obtained benchmark coordinates in a common reference frame by considering the daily loosely constrained estimates and their associated variance-covariance matrices as quasi-observations and passing them to GLOBK which employs the Kalman filtering approach. The reference frame during the formation of these combined network solutions was again loosely defined until the last processing step, where we realized a common reference frame applying generalized constraints (Dong et al., 1998; 2002) and aligning each individual daily solution to the 2008 realization of the International Terrestrial Reference Frame. This was done by minimizing, in the least-square sense, the departure from the values determined by IERS of 18 IGS stations which were also incorporated in the GAMIT 
processing part in order to serve as ties with the ITRF2008 (Altamimi et al., 2012) (Figure 4). Four additional, continuously recording GPS stations throughout Greece (NOA1, AUT1, DUTH, KLOK), the first three of them part of the EUREF Permanent Network (EPN; http://www.epncb.oma.be/; KLOK is part of NOANET, Ganas et al., 2011), were also incorporated in the processing scheme thus gaining in efficiency and validation.

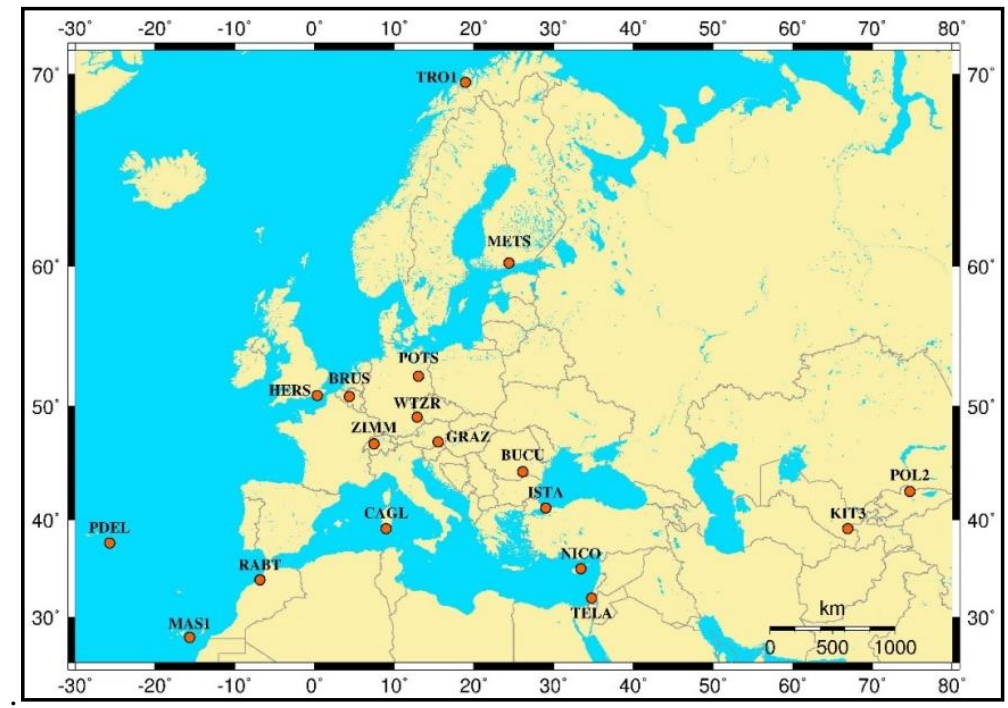

Figure 4 - Distribution of IGS stations (orange dots) used in GPS data processing.

Table 1 - Absolute vertical displacements of the mobile GNSS stations as differences of ellipsoidal heights from each campaign to its next. Values are in metres.

\begin{tabular}{|c|c|c|c|c|c|c|c|c|}
\hline Station & $1^{\text {st }}$ Period & $2^{\text {nd }}$ Period & $3^{\text {rd }}$ Period & $4^{\text {th }}$ Period & $2^{\text {nd }}-1^{\text {st }}(\mathrm{m})$ & $3^{\text {rd }}-2^{\text {nd }}(\mathrm{m})$ & $4^{\text {th }}-3^{\text {rd }}(\mathrm{m})$ & $4^{\text {th }}-1^{\text {st }}(\mathrm{m})$ \\
\hline KA02 & 20131031 & 20140411 & 20141104 & 20150403 & -0.0070 & -0.0037 & 0.0050 & -0.0057 \\
\hline KA03 & 20131031 & 20140411 & 20141104 & 20150403 & -0.0266 & 0.0079 & -0.0073 & -0.0259 \\
\hline KA04 & 20131031 & 20140411 & 20141104 & 20150403 & 0.0177 & 0.0003 & -0.0034 & 0.0146 \\
\hline KA05 & 20131031 & 20140411 & 20141104 & 20150403 & -0.0376 & 0.0270 & 0.0222 & 0.0117 \\
\hline KA06 & 20131031 & 20140411 & 20141104 & 20150403 & 0.0035 & 0.0046 & 0.0119 & 0.0200 \\
\hline KA07 & 20131101 & 20140412 & 20141105 & 20150404 & 0.0213 & -0.0235 & 0.0302 & 0.0280 \\
\hline KA08 & 20131101 & 20140412 & 20141105 & 20150404 & 0.0079 & -0.0030 & -0.0068 & -0.0020 \\
\hline KA10 & 20131101 & 20140412 & 20141105 & 20150404 & -0.0230 & 0.0124 & 0.0145 & 0.0039 \\
\hline KA11 & 20131101 & 20140412 & 20141105 & 20150404 & 0.0189 & 0.0106 & 0.0178 & 0.0473 \\
\hline KA12 & 20131101 & 20140412 & 20141105 & 20150404 & -0.0177 & 0.0040 & 0.0116 & -0.0021 \\
\hline KA13 & 20131102 & 201404-13 & 20141106 & 20150405 & -0.0120 & -0.0001 & 0.0019 & -0.0102 \\
\hline KA14 & 20131031 & 20140411 & 20141104 & 20150403 & -0.0018 & -0.0190 & 0.0254 & 0.0046 \\
\hline KA15 & 20131102 & 201404-13 & 20141106 & 20150405 & 0.0023 & 0.0138 & -0.0139 & 0.0022 \\
\hline KA16 & 20131102 & 201404-13 & 20141106 & 20150405 & -0.0575 & 0.0280 & 0.0049 & -0.0246 \\
\hline KA17 & 20131102 & 201404-13 & 20141106 & 20150405 & 0.0207 & -0.0018 & 0.0071 & 0.0260 \\
\hline KA18 & 20131102 & 201404-13 & 20141106 & 20150405 & -0.0023 & 0.0242 & -0.0076 & 0.0142 \\
\hline KA19 & 20131101 & 20140412 & 20141105 & 20150404 & -0.0124 & 0.0100 & 0.0172 & 0.0149 \\
\hline KA20 & 201311-02 & 201404-13 & 20141106 & 20150405 & -0.0222 & 0.0254 & 0.0044 & 0.0076 \\
\hline
\end{tabular}


The largest difference in the vertical component (campaign 4-1) is obtained at benchmarks KA03, KA07, KA11, KA16 and KA17, with values exceeding $2 \mathrm{~cm}$ of motion (Table 1). KA11 shows the largest motion (uplift) of $4.7 \mathrm{~cm}$. KA03 shows the largest subsidence of $2.7 \mathrm{~cm}$. The displacement graphs for the latter stations are plotted in Figure 5 (KA11 is located on the central section of the dam while KA03 is located on the main road of Kalochori, 28 Octovriou Str.). Due to the closeness of KA03 mean to the margins of error we reprocessed the data with the GIPSY v6.4 software (https://gipsy-oasis.jpl.nasa.gov/) in PPP mode using ionosphere free linear combination. We were able to confirm our GAMIT subsidence trend, in fact subsidence was found as low $4 \mathrm{~cm}$ (see Fig. 5). Table 1 data were inserted into ArcGIS and the difference (in m) between campaigns 1 and 4 (41) is presented in the map of Figure 6 by use of Inverse distance weighted (IDW) interpolation (Shepard, 1968). For comparison with campaign data we also present time series from two, colocated permanent GNSS stations in Kalochori, namely KAL1 and KAL2 (Figure 7). KAL1 is located near KAL04 (Fig. 1) while KAL2 near KAL05. These stations are equipped with LEICA geodetic equipment and were installed during 2013. They provided 30-s daily observations for almost 1.5 years, a period not enough for complete evaluation of their signals. Nevertheless, their vertical component data also show a rather stable behaviour (Fig. 7) as of June 2015. This preliminary result agrees with campaign data in the main urban area of Kalochori (Fig. 6), i.e. it indicates motions in the range -1 to $+2 \mathrm{~cm}$.

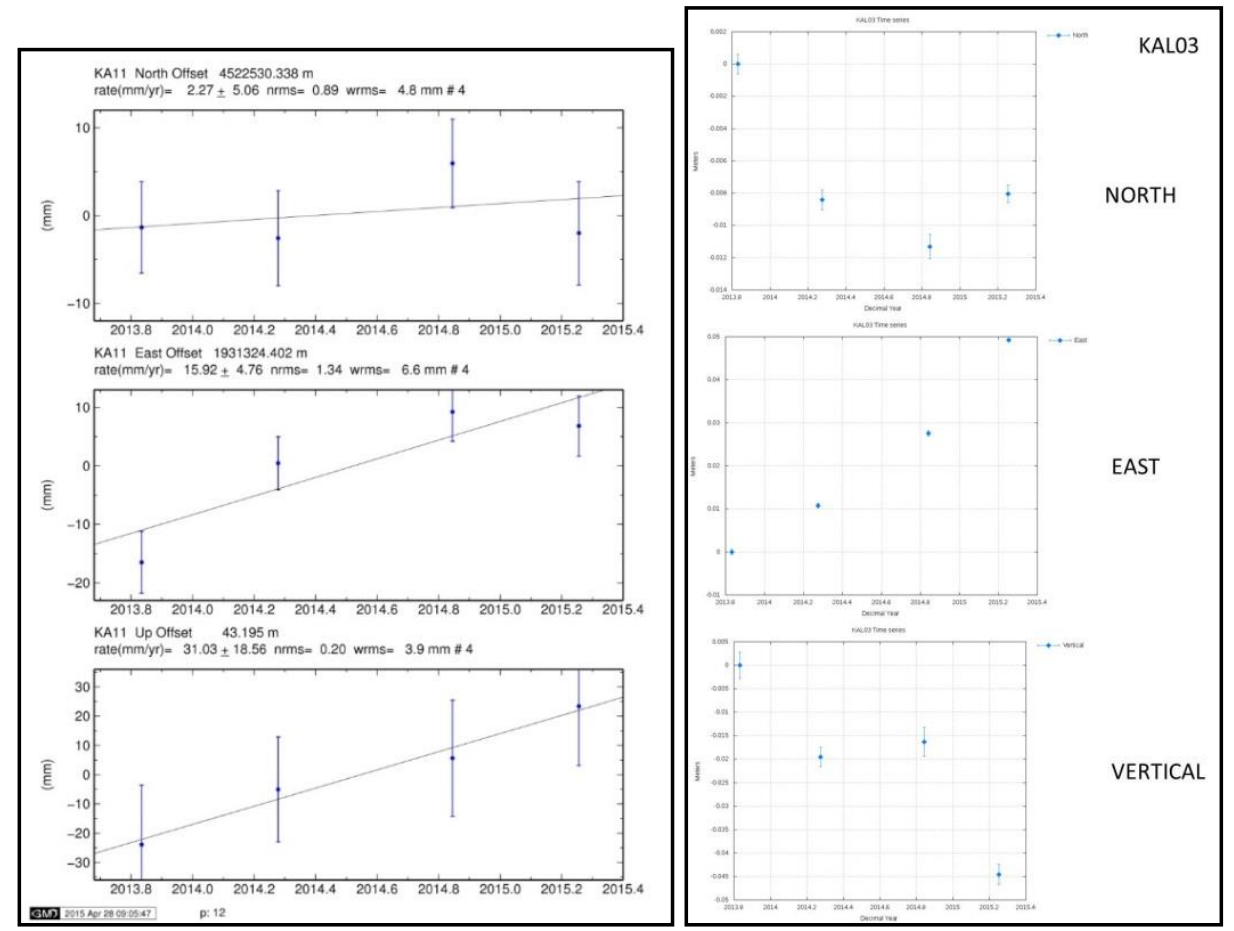

Figure 5 - Displacement (ITRF2008) vs time graphs for stations, KA11 (left) and KA03 (right). Thin gray lines show motion trends. Note the difference in Y-scale in the two plots. 


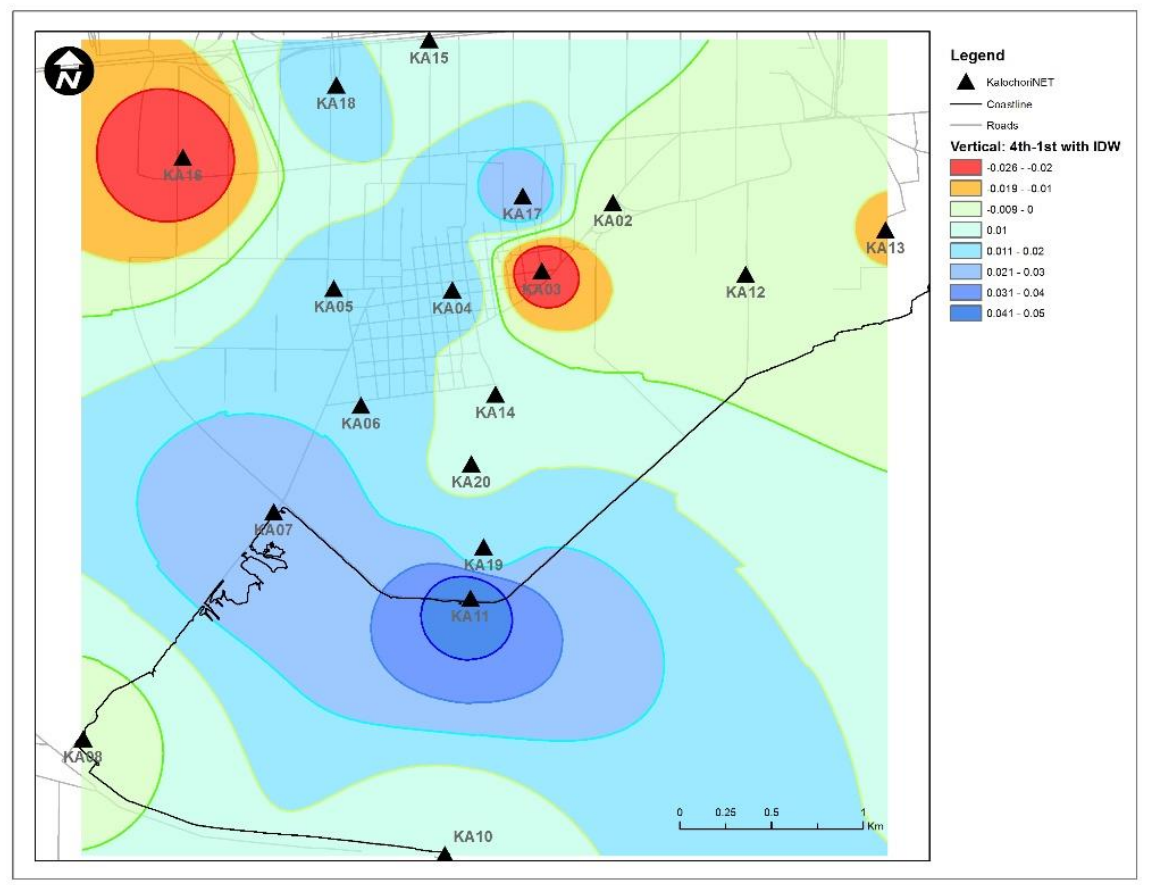

Figure 6 - Vertical displacement map for the Kalochori region, during 2013-2015. Colours from red to blue show subsidence to uplift, respectively. Scale is in $\mathbf{m}$.

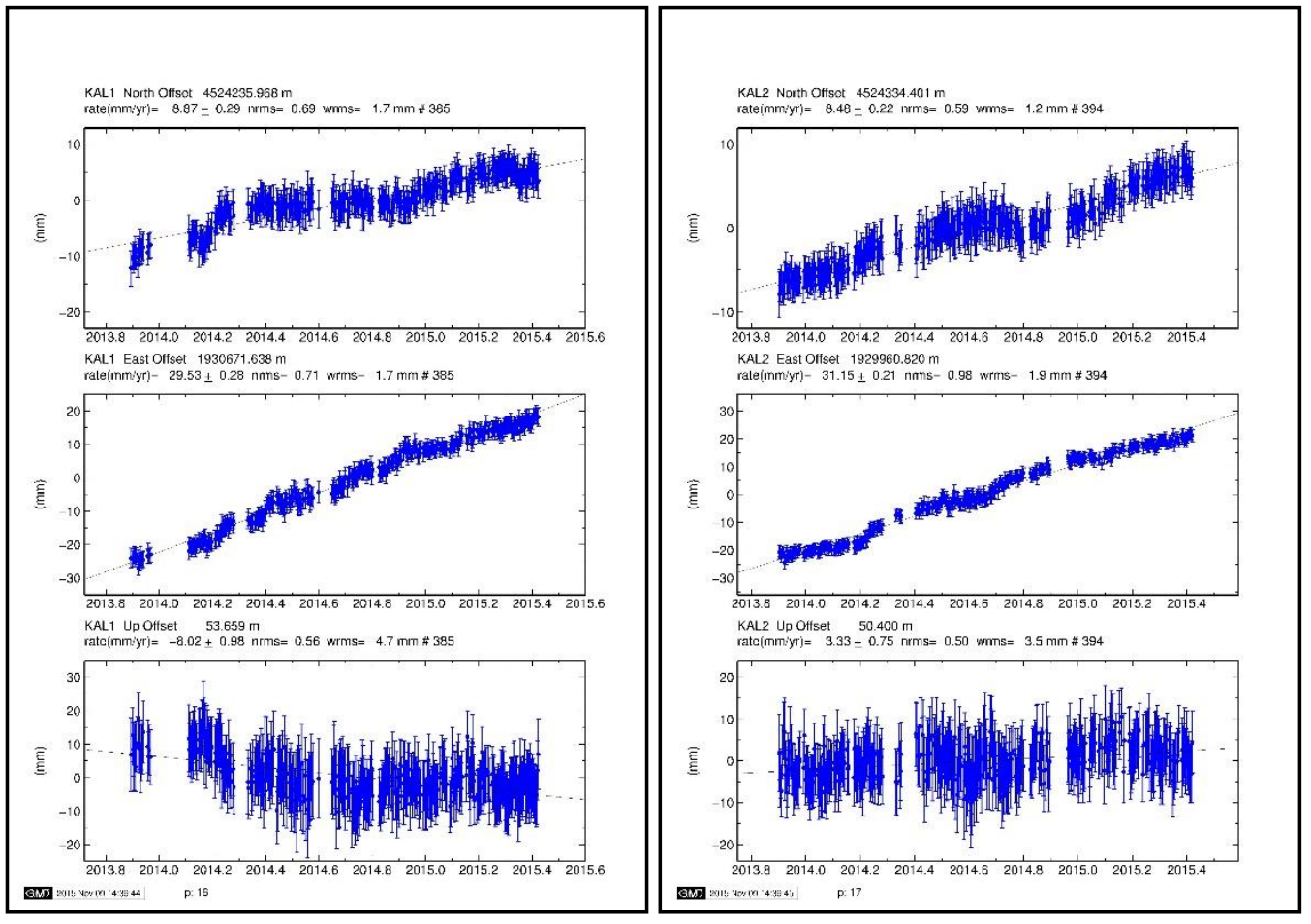

Figure 7 - Position Time series (3-components) of permanent GNSS stations in Kalochori, obtained by GAMIT/GLOBK software. 


\section{Conclusions}

Our GPS measurements (Table 1, Fig. 6, Fig. 7) during the period 2013-2015, in the greater region of Kalochori, show vertical motions ranging from $-2 \mathrm{~cm}$ to $+2 \mathrm{~cm}$ (i.e. just above the margins of measurement error) with the exception of the dam south perimeter where an uplift of $2-5 \mathrm{~cm}$ was observed (Figure 6). We also found no evidence for local (non-tectonic) motions and/or interseismic strain.

\section{Acknowledgements}

This research was funded by GSRT (General Secretariat for Research and Technology of Greece) project INDES-MUSA “INnovative multi-sensor network for DEformation \& Seismic Monitoring of Urban Subsidence-prone Areas". We thank local authorities (Delta Municipality) and our INDESMUSA colleagues for help with network setup. We acknowledge useful comments throughout the course of this research by Elias Tziavos, Manolis Rovithis, Alekos Savvaidis, Betty Charampopoulou, Charis Manessis and Costas Loupasakis. Many thanks are due to P. Grigorakakis for this help with GPS rover operations.

\section{References}

Altamimi, Z., Metivier, L. and Collilieux, X., 2012. ITRF2008 plate motion model, Journal of Geophysical Research, 117(7), B07402, doi: 10.1029/2011JB008930.

Andronopoulos, V., 1979. Geological and geotechnical study in the Kalochori (Thessaloniki) area, Report, Institute of Geology and Mineral Exploration (IGME), Athens.

Andronopoulos, V., Rozos, D. and Hatzinakos, I., 1990. Geotechnical study of ground settlement in the Kalochori area, Thessaloniki District, Report, Institute of Geology and Mineral Exploration, IGME, Athens.

Andronopoulos, V., Rozos, D. and Hatzinakos, I., 1991. Subsidence phenomena in the industrial area of Thessaloniki, Greece. In: Jonshon, A., ed., Land Subsidence, IAHS Publications, 200, 59-69.

Badelas, A., Savvaidis, P., Ifadis, I. and Doukas, I. 1996. Monitoring of ground subsidence in the area of Kalohori by using a high precision leveling control network, Technical Report No. 2853, Research Committee, Aristotle University of Thessaloniki, 157 pp.

Chousianitis, K., Ganas, A. and Evangelidis, C.P., 2015. Strain and rotation rate patterns of mainland Greece from continuous GPS data and comparison between seismic and geodetic moment release, Journal of Geophysical Research, 120, doi: 10.1002/2014JB011762.

Dimopoulos, G., 2005. Investigation of the conditions generating soil settlements in SindosKalochori area of Thessaloniki. In: Stournaras, G., Pavlopoulos, K. and Bellos, Th., eds., Proc. of the 7th Hellenic Hydrogeological Conference and 2nd MEM Workshop on Fissured Rocks Hydrogeology, 1, Hellenic Committee of Hydrogeology, Athens, 135-146.

Dong, D.N., Herring, T.A. and King, R.W., 1998. Estimating regional deformation from a combination of space and terrestrial geodetic data, Journal of Geodesy, 72, 200-214.

Dong, D.N., Fang, P., Bock, Y., Cheng, M.K. and Miyazaki, S., 2002. Anatomy of apparent seasonal variations from GPS-derived site position time series, Journal of Geophysical Research, 107(B4), 2075, doi: 10.1029/2001JB000573.

Doukakis, E., 2005. Coastal red spots along the western Thermaikos gulf. In: Lekkas, T.D., ed., Proc. of the 9th International Conference on Environmental Science and Technology, Rhodes, Greece, University of Aegean, Rhodes, A334-A339.

Estey, L.H. and Meertens, C.M., 1999. TEQC: The Multi-Purpose Toolkit for GPS/GLONASS Data, GPS Sol.3, 42-49.

Ganas, A., Chousianitis, K., Drakatos, G., Papanikolaou, M., Argyrakis, P., Kolligri, M., Petrou, P., Batsi, E. and Tsimi, Ch., 2011. NOANET: High-rate GPS Network for Seismology and Geodynamics in Greece, Abstracts of EGU2011 General Assembly, Vienna, Austria, 13, Abstract EGU2011-4840. 
Hatzinakos, I., Rozos, D. and Andronopoulos, E., 1990. Engineering geological mapping and related geotechnical problems in the wider industrial area of Thessaloniki, Greece. In: Price, D., ed., Proc. of the $6^{\text {th }}$ International IAEG Congress, Balkema, Rotterdam, 127-134.

Herring, T.A., King, R.W. and McClusky, S., 2010. Documentation for the GAMIT/GLOBK GPS processing software release 10.4, Mass. Inst. of Technol., Cambridge.

Loupasakis, K. and Rozos, D., 2009a. Finite-element simulation of land subsidence induced by water pumping in Kalochori village, Greece, Quarterly Journal of Engineering Geology and Hydrogeology, 42, 369-382.

Loupasakis, C. and Rozos D., 2009b. Land Subsidence Induced by Water Pumping in Kalochori Village (North Greece) - Simulation of the Phenomenon by Means of the Finite Element Method, Quarterly Journal of Engineering Geology and Hydrogeology, 42, 3, 369-382.

Lyard, F., Lefevre, F., Letellier, T. and Francis, O., 2006. Modelling the global ocean tides: modern insights from FES2004, Ocean Dynamics, 56(5-6), 394-415, doi: 10.1007/s10236-006-0086-x.

McCarthy, D.D. and Petit, G., 2004. IERS Conventions 2003, IERS Technical Note 32, Verlag des Budesamts fur Kartographie und Geodasie, Frankfurt.

Pavlides, S.B. and Kilias, A.A., 1987. Neotectonic and active faults along the Serbomacedonian zone (SE Chalkidiki, Northern Greece), Ann. Tectonicae, 1, 9-104.

Psimoulis, P., Ghilardi, M., Fouache, E. and Stiros, S., 2007. Subsidence and evolution of the Thessaloniki Plain, Greece, based on historical leveling and GPS data, Engineering Geology, 90, 55-70.

Rovithis, E., Charalampopoulou, B., Ganas, A., Savvaidis, A., Makra, K., Konstantinidou, K., Kirtas, E., Karakostas, Ch., Lekidis, V., Pitilakis, D., Loupasakis, C., Tsimi, Ch. and Manesis, Ch., 2014. INDES-MUSA Project - Integrated monitoring of subsiding coastal areas prone to large earthquakes: the case of Kalochori in Greece, Proc. of the 2nd European Conference on Earthquake Engineering and Seismology, Istanbul, 24-29August, paper No. 2739.

Rozos, D. and Hatzinakos, I., 1993. Geological conditions and geomechanical behaviour of the Neogene sediments in the area west of Thessaloniki (Greece). In: Anagnostopoulos, A., ed., Proc. of International Symposium on Geotechnical Engineering of Hard Soils-Soft Rocks, Greece, 1. Balkema, Rotterdam, 269-274.

Rozos, D., Andronopoulos, E. and Hatzinakos, I., 2004. Engineering-geological map of Thessaloniki wider area, Greece, Bulletin of Engineering Geology and the Environment, 63, 103-108.

Shepard, D., 1968. A two-dimensional interpolation function for irregularly-spaced data, Proc. of the 1968 ACM National Conference, 517-524.

Stiros, S., 2001. Rapid subsidence of the Thessaloniki (Northern Greece) coastal plain, 1960-1999, Engineering Geology, 61, 243-256. 